\title{
Clinical outcomes after percutaneous coronary intervention with the COMBO stent versus Resolute Integrity and PROMUS Element stents: a propensity-matched analysis
}

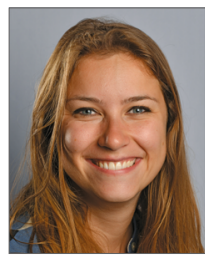

\author{
Deborah N. Kalkman¹, MD; Marlies M. Kok², MD; Liefke C. van der Heijden², MD; \\ Pier Woudstra ${ }^{1}, \mathrm{MD}$; Marcel A.M. Beijk¹, MD, PhD; Jan G.P. Tijssen ${ }^{1}$, PhD; \\ Clemens von Birgelen ${ }^{2,3}, \mathrm{MD}, \mathrm{PhD}$; Robbert J. de Winter ${ }^{1 *}, \mathrm{MD}, \mathrm{PhD}$; \\ on behalf of the REMEDEE registry investigators and DUTCH PEERS investigators
}

1. Academic Medical Center - University of Amsterdam, Amsterdam, the Netherlands; 2. Thoraxcentrum Twente, Medisch Spectrum Twente, Enschede, the Netherlands; 3. University of Twente, Enschede, the Netherlands

D.N. Kalkman, M.M. Kok and L.C. van der Heijden contributed equally to this manuscript.

This paper also includes supplementary data published online at: http://www.pcronline.com/eurointervention/125th_issue/188

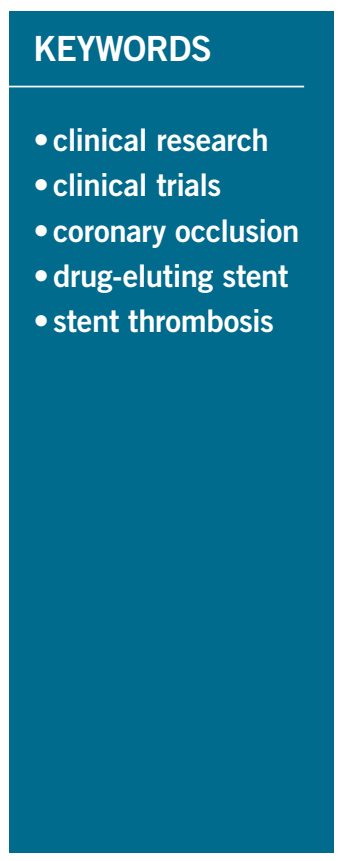

\begin{abstract}
Aims: The COMBO stent combines sirolimus elution with an endothelial progenitor cell-capturing layer to promote early endothelialisation. There has not been a head-to-head comparison of this novel device with any other currently used drug-eluting stent (DES). We sought to compare clinical outcome at two years after COMBO stent placement with the Resolute Integrity or PROMUS Element stent in an all-comers cohort.

Methods and results: Patients from the REMEDEE registry (COMBO, $n=1,000)$ were matched with patients from the DUTCH PEERS trial (PROMUS Element/Resolute Integrity, $n=1,811$ ). Propensity score matching on 13 baseline characteristics was applied to create two balanced cohorts of patients treated with COMBO versus PROMUS Element/Resolute Integrity. Propensity score matching yielded 771 patient pairs, representing all-comers patients, with a median age of 65 years, $27 \%$ female and more than $50 \%$ of patients presenting with acute coronary syndrome. Target lesion failure (TLF), a composite of cardiac death, target vessel MI and any target lesion revascularisation, at two-year follow-up was $7.9 \%$ in COMBO and $6.4 \%$ in PROMUS Element/Resolute Integrity, HR 1.24 (95\% CI: 0.85-1.81), $\mathrm{p}=0.26$. Definite stent thrombosis (ST) was not significantly different between groups ( $0.8 \%$ vs. $0.9 \%, \mathrm{p}=0.79)$.
\end{abstract}

Conclusions: In a propensity-matched analysis, the COMBO stent showed similar rates of TLF and ST at two-year follow-up compared to Resolute Integrity and PROMUS Element.

\footnotetext{
*Corresponding author: Department of Cardiology, room B2-137, Academic Medical Center-University of Amsterdam, Meibergdreef 9, 1105 AZ Amsterdam, the Netherlands.E-mail:r.j.dewinter@amc.uva.nl
} 


\section{Abbreviations}

CABG coronary artery bypass grafting

DES drug-eluting stent

EPC endothelial progenitor cell

MI myocardial infarction

NSTE-ACS non-ST-segment elevation acute coronary syndrome

PCI percutaneous coronary intervention

ST stent thrombosis

STEMI ST-segment elevation myocardial infarction

TLF target lesion failure

TLR target lesion revascularisation

\section{Introduction}

Clinical outcomes after percutaneous coronary intervention (PCI) with stent placement are strongly related to the device type that is implanted. Drug-eluting stents (DES) improved outcomes compared to bare metal stents in terms of in-stent restenosis ${ }^{1-3}$. Further developments in coronary DES led to different metal platforms, drug types, mechanisms of drug release, and polymer coatings ${ }^{4}$. A novel stent that has been developed to reduce adverse outcomes after PCI further is the dual-therapy $\mathrm{COMBO}^{\mathrm{TM}}$ stent (OrbusNeich Medical BV, Hoevelaken, the Netherlands) ${ }^{5,6}$.

The COMBO stent combines a biodegradable abluminal sirolimus-eluting polymer with a unique luminal endothelial progenitor cell-capturing layer. This stent technique aims to promote true vessel healing and thereby improve clinical outcome after PCI. Two-year clinical outcomes after COMBO stent deployment were evaluated in the all-comers REMEDEE registry ${ }^{7,8}$. Thus far, no randomised data are available comparing the dual-therapy stent technology with new-generation DES such as the Resolute Integrity $^{\circledR}$ zotarolimus-eluting stent (Medtronic, Minneapolis, MN, USA) and the PROMUS Element ${ }^{\mathrm{TM}}$ everolimus-eluting stent (Boston Scientific, Marlborough, MA, USA) ${ }^{9-11}$. These newer-generation durable polymer drug-eluting stents have been shown to be similarly safe and efficacious ${ }^{11}$.

The objective of the current analysis was to compare the twoyear clinical outcomes of the COMBO stent with Resolute Integrity and PROMUS Element stent therapy in a balanced cohort. This analysis is the first to compare results after COMBO stent placement with other DES and will provide additional insight into the clinical performance of the COMBO stent.

\section{Methods}

\section{DEVICES}

The three investigational devices are the PROMUS Element, the Resolute Integrity and the COMBO stent. All stents are CE-marked (available on the European market) and used in daily clinical practice. The PROMUS Element consists of a thin fluoropolymer everolimus coating on a stent platform made from a platinum-chromium alloy which has a novel, laser-cut, open-cell stent design, consisting of serpentine rings connected by helically distributed links ${ }^{9}$. The Resolute Integrity consists of a BioLinx zotarolimus coating on a cobalt-chromium alloy stent platform that has a sinusoidal design. The BioLinx polymer system of this stent consists of a blend of three different polymers: the hydrophobic $\mathrm{C} 10$ polymer, aiding drug release; a hydrophilic $\mathrm{C} 19$ polymer, supporting biocompatibility; and a polyvinylpyrrolidone, which increases the initial drug burst and enhances the elution rate ${ }^{10}$. The COMBO consists of a $316 \mathrm{~L}$ stainless steel alloy in a helical sinusoidal design and an abluminal biodegradable sirolimus-eluting polymer layer, with a bio-engineered anti-CD34+ antibody layer to attract endothelial progenitor cells.

\section{TRIALS}

The DUTCH PEERS trial is a prospective, investigator-initiated, all-comers, randomised (1:1), non-inferiority trial comparing clinical outcomes after PROMUS Element and Resolute Integrity stent placement. The study design and primary results have been published in more detail elsewhere ${ }^{11}$. In short, a total of 1,811 patients were enrolled between November 2010 and May 2012 at four PCI centres in the Netherlands (PROMUS Element, $\mathrm{N}=905$, Resolute Integrity, $\mathrm{N}=906$ ). Based on the primary endpoint of target vessel failure, non-inferiority of the Resolute Integrity stent was proven, compared with the PROMUS Element stent, and both stents were similarly efficacious and safe in an all-comers population ${ }^{11}$. At two-year follow-up, similar clinical outcomes were reported for both DES examined ${ }^{12}$.

The REMEDEE registry is a prospective, investigator-initiated, all-comers, single-arm registry of 1,000 patients treated with the COMBO stent. The study was conducted in nine European sites across the Netherlands, Latvia, Luxembourg, Northern Ireland and Spain. Enrolment started in June 2013 and was completed in March 2014. Registry design and clinical results have been published previously ${ }^{7,8}$. All events were adjudicated by an independent clinical events committee.

In the REMEDEE registry, DAPT regimen was advised to follow current guidelines: six to 12 months after elective PCI, 12 months after acute coronary syndrome (ACS). The DUTCH PEERS trial recommended prescription of aspirin and clopidogrel for 12 months after PCI. Both studies complied with the Declaration of Helsinki, and were approved by the independent medical ethics committees and institutional review boards of all participating centres. The DUTCH PEERS trial complied with the CONSORT 2010 statement. All patients in the studies provided written informed consent.

\section{PATIENT POPULATION}

Inclusion criteria were identical between the two studies. The following inclusion criteria were used: patients undergoing PCI with stent treatment, $>18$ years old and willing and able to cooperate with study requirements. Exclusion criteria in both trials were: high probability of non-adherence to the follow-up requirements (due to social, psychological or medical reasons), currently participating in another investigational drug or device study in which a routine angiographic follow-up is planned, a life expectancy of $<1$ year. Additional exclusion criteria for the DUTCH PEERS trial 
were: known pregnancy or intolerance to a $\mathrm{P} 2 \mathrm{Y}_{12}$ receptor antagonist, aspirin, heparin or any of the components of the DES.

\section{CLINICAL ENDPOINTS AND DEFINITIONS}

The primary outcome of interest was target lesion failure (TLF), a composite endpoint of cardiac death, target vessel-related myocardial infarction (MI), or any target lesion revascularisation at two years. Stent thrombosis (definite, definite or probable) at two years was evaluated. Two-year follow-up was defined as 720 days post index procedure. Endpoints were defined according to the Academic Research Consortium including the addendum on myocardial infarction ${ }^{13,14}$. Furthermore, we looked at the individual components of the endpoint TLF separately, i.e, cardiac death, target vessel MI and target lesion revascularisation.

\section{STATISTICAL ANALYSIS (ENTIRE COHORT)}

Categorical variables are presented as numbers and percentages and are compared for the entire cohort with Fisher's exact test. Based on their distributions, continuous variables are presented as mean \pm standard deviation or median with interquartile ranges and compared with the Student's t-test or Wilcoxon rank-sum test, or Kruskal-Wallis test in case of non-normally distributed variables.

\section{PROPENSITY SCORE MATCHING}

A pre-specified analysis plan was made prior to the conduct of the analysis to eliminate (potential) model bias, including a consensus on the matching variables. Propensity score matching was performed using the following thirteen selected baseline variables: age, gender, insulin-treated diabetes mellitus, hypertension, previous MI, previous PCI, previous bypass, ACS, number of treated lesions, target vessel location, stent length and diameter, and American College of Cardiology/American Heart Association (ACC/AHA) classification. A logistic multivariable regression was used with device type (PROMUS Element or Resolute Integrity versus COMBO) as dependent variable and the 13 above listed baseline variables as independent predictors to calculate the propensity score. Patients were one-to-one greedy matched using the nearest neighbour method, COMBO versus either PROMUS Element or Resolute Integrity. The calliper for the propensity match was set at 0.2 .

All statistical analyses were conducted in R Studio and $\mathrm{R}$ version 3.2.2 and the package MatchIt for propensity matching 17 and 18 (The R Foundation for Statistical Computing, Vienna, Austria). All reported $\mathrm{p}$-values were two-tailed, and $\mathrm{p}<0.05$ was considered statistically significant.

\section{SENSITIVITY ANALYSES}

Sensitivity analyses were performed per stent device (COMBO versus Resolute Integrity, COMBO versus PROMUS) using the same method of propensity score matching.

\section{ANALYSIS OF THE MATCHED COHORT}

Baseline variables of the matched cohort were compared with the same methods as the unmatched cohorts. Kaplan-Meier estimates
Table 1. Baseline patient, lesion and stent characteristics in the matched cohort.

\begin{tabular}{|c|c|c|c|}
\hline & $\begin{array}{c}\text { PROMUS } \\
\text { Element/ } \\
\text { Resolute } \\
\text { Integrity } \\
n=771\end{array}$ & $\begin{array}{l}\text { COMBO } \\
n=771\end{array}$ & $p$-value \\
\hline Female (\%) & 215 (27.9) & $206(26.7)$ & 0.647 \\
\hline $\begin{array}{l}\text { Age at randomisation } \\
\text { (years) }\end{array}$ & $64.06( \pm 10.93)$ & $64.78( \pm 11.21)$ & 0.204 \\
\hline Diabetes mellitus (\%) & 138 (17.9) & $141(18.3)$ & 0.895 \\
\hline Insulin-treated DM (\%) & $44(5.7)$ & $47(6.1)$ & 0.829 \\
\hline Hypertension (\%) & $436(56.5)$ & $440(57.1)$ & 0.877 \\
\hline Previous CABG (\%) & $54(7.0)$ & $52(6.7)$ & 0.920 \\
\hline Previous PCI (\%) & $187(24.3)$ & $200(25.9)$ & 0.481 \\
\hline Previous MI (\%) & $164(21.3)$ & $177(23.0)$ & 0.462 \\
\hline $\begin{array}{l}\text { Acute coronary syndrome } \\
(\%)\end{array}$ & $420(54.5)$ & $406(52.7)$ & 0.507 \\
\hline LAD treated $(\%)$ & 369 (47.9) & $373(48.4)$ & 0.878 \\
\hline LCX treated (\%) & $188(24.4)$ & $199(25.8)$ & 0.557 \\
\hline Left main treated $(\%)$ & $12(1.6)$ & $12(1.6)$ & 1.000 \\
\hline RCA treated $(\%)$ & $235(30.5)$ & $234(30.4)$ & 1.000 \\
\hline Graft treated (\%) & $11(1.4)$ & $14(1.8)$ & 0.687 \\
\hline \multicolumn{4}{|c|}{ Number of treated lesions (\%) } \\
\hline 0 & $0(0.0)$ & $1(0.1)$ & \multirow{4}{*}{0.294} \\
\hline 1 & 669 (86.8) & $651(84.4)$ & \\
\hline 2 & $93(12.1)$ & $103(13.4)$ & \\
\hline 3 & $9(1.2)$ & $16(2.1)$ & \\
\hline \multicolumn{4}{|c|}{ AHA/ACC lesion type (worst) (\%) } \\
\hline A & $53(6.9)$ & $127(16.5)$ & \multirow{4}{*}{$<0.001$} \\
\hline B1 & 257 (33.3) & $183(23.7)$ & \\
\hline B2 & $321(41.6)$ & $287(37.2)$ & \\
\hline C & $140(18.2)$ & $174(22.6)$ & \\
\hline $\begin{array}{l}\text { Max stent diameter } \\
\text { (median [IQR]) }\end{array}$ & $\begin{array}{c}3.00 \\
{[3.00,3.50]}\end{array}$ & $\begin{array}{c}3.00 \\
{[3.00,3.50]}\end{array}$ & 0.883 \\
\hline $\begin{array}{l}\text { Total stent length } \\
\text { (median [IQR]) }\end{array}$ & $\begin{array}{c}20.00 \\
{[15.00,28.00]}\end{array}$ & $\begin{array}{c}18.00 \\
{[15.00,28.00]}\end{array}$ & 0.751 \\
\hline \multicolumn{4}{|c|}{$\begin{array}{l}\text { Values are mean } \pm S D \text { or } n \text { (valid \%). PROMUS Element } n=375 \text {, Resolute } \\
\text { Integrity } n=396 \text {. }\end{array}$} \\
\hline
\end{tabular}

were used for the cumulative incidence of outcomes at two-year follow-up. P-values and hazard ratios were calculated using Cox proportional hazards $(\mathrm{CPH})$ models. $\mathrm{CPH}$ assumptions were visually inspected by plotting Schoenfeld residuals. P-values $<0.05$ were considered statistically significant.

\section{Results}

\section{PATIENT AND ANGIOGRAPHIC CHARACTERISTICS FROM THE DUTCH PEERS TRIAL AND THE REMEDEE REGISTRY}

The baseline characteristics of both trials have been published previously $^{7,9}$, and are summarised in Supplementary Table 1. REMEDEE registry patients are older, have more hypertension, 
more previous PCI and previous MI. Acute coronary syndrome was more present in the DUTCH PEERS trial, and the RCA was treated more frequently in DUTCH PEERS. Significant differences were also found in the number of treated lesions, AHA/ACC lesion type and lesion length.

\section{PATIENT AND ANGIOGRAPHIC CHARACTERISTICS OF THOSE IN THE MATCHED COHORTS}

The propensity score calculation was performed taking into account the thirteen baseline and angiographic variables. The propensity score match resulted in 771 balanced patient pairs, as illustrated in Table 1. AHA/ACC lesion type could not be perfectly matched (taking into account the four lesion types). The combined type $\mathrm{B} 2 / \mathrm{C}$ was the same, both $59.8 \%$.

\section{CLINICAL OUTCOMES AT TWO YEARS IN THE MATCHED COHORTS}

TLF at two-year follow-up in the matched cohort by KaplanMeier estimate is shown in Figure 1. TLF occurred in $7.9 \%$ of patients treated with the COMBO, and in $6.4 \%$ of patients treated with PROMUS Element/Resolute Integrity $(\mathrm{p}=0.26)$, HR 1.24 (95\% CI: 0.85-1.81). Cardiac death (Figure 2A) occurred in $2.9 \%$ versus $2.1 \%(\mathrm{p}=0.31)$, HR 1.39 (95\% CI: 0.73-2.65); target vessel MI (Figure 2B) in $1.2 \%$ versus $1.3 \%(\mathrm{p}=0.82)$, HR 0.90 (95\% CI: $0.37-2.22)$; and TLR (Figure $2 \mathrm{C}$ ) in $5.6 \%$ versus $3.8 \%(\mathrm{p}=0.11)$, HR 1.48 (95\% CI: 0.92-2.37), respectively. Definite stent thrombosis occurred in $0.8 \%$ of the COMBO patients and in $0.9 \%$ of the PROMUS Element/Resolute Integrity patients $(p=0.79)$, HR 0.86 (95\% CI: 0.29-2.57) (Figure 3). Definite or probable stent thrombosis was observed in $0.9 \%$ versus $1.0 \%$ of patients $(\mathrm{p}=0.8)$, HR 0.88 (95\% CI: 0.32-2.43), respectively. Results are presented in Table 2.

\section{SENSITIVITY ANALYSES}

Sensitivity analyses were conducted per device type. Two sets of patient pairs were made for COMBO and Resolute Integrity (both

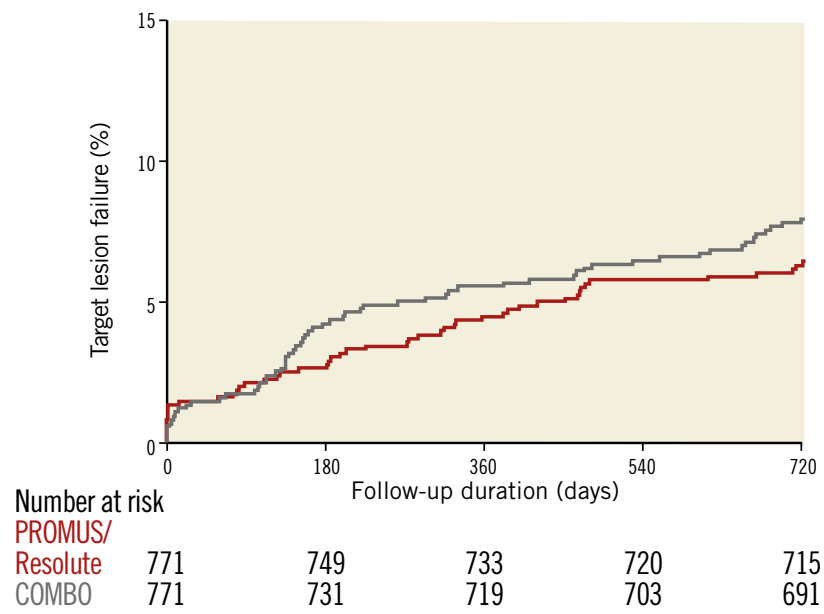

Figure 1. Target lesion failure by Kaplan-Meier method.
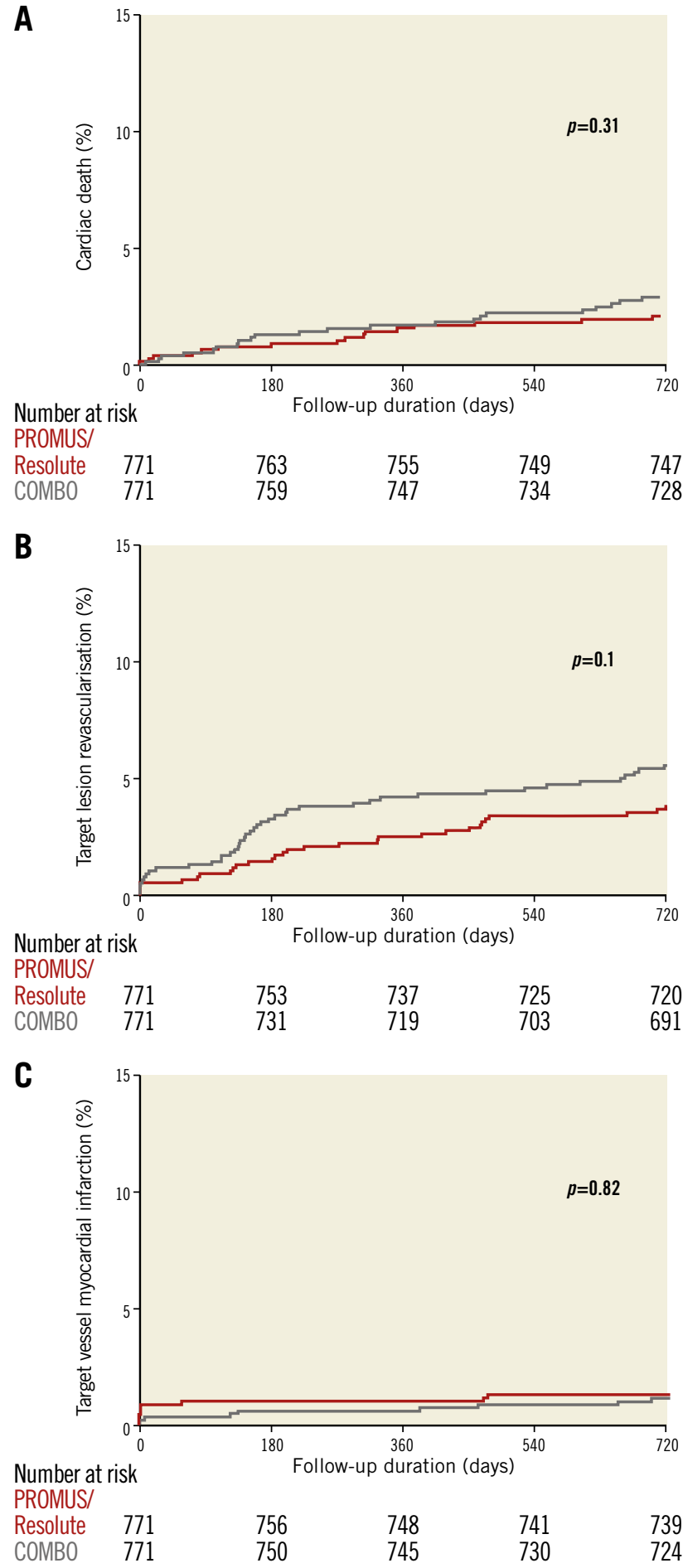

Figure 2. Cardiac death, TLR and TV-MI by Kaplan-Meier method.

$\mathrm{n}=588$ ). Baseline and angiographic characteristics were nicely balanced (Supplementary Table 2). The evaluation of TLF at twoyear follow-up shows $8.4 \%$ for COMBO and $7.2 \%$ for Resolute Integrity $(p=0.43)$ (Supplementary Table 3). Sensitivity analysis for the comparison of COMBO with PROMUS Element also resulted in two balanced cohorts (both $n=617$ ), and evaluation of TLF showed $7.4 \%$ for COMBO and $5.5 \%$ for PROMUS Element $(\mathrm{p}=0.19)$ (Supplementary Table 4, Supplementary Table 5). 


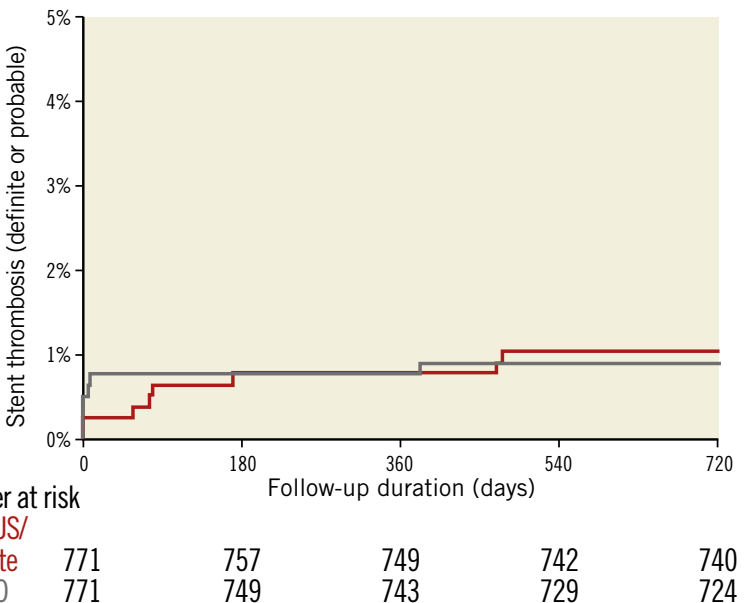

Figure 3. Definite or probable stent thrombosis by Kaplan-Meier method.

Table 2. Number of events and Kaplan-Meier estimates of COMBO and Resolute Integrity/PROMUS Element at 2-year follow-up.

\begin{tabular}{|l|c|c|c|}
\hline & $\begin{array}{c}\text { COMBO } \\
\text { N=771 }\end{array}$ & $\begin{array}{c}\text { PROMUS } \\
\text { Element/ Resolute } \\
\text { Integrity N=771 }\end{array}$ & p-value \\
\hline TLF & $60(7.9)$ & $49(6.4)$ & 0.26 \\
\hline Cardiac death & $22(2.9)$ & $16(2.1)$ & 0.31 \\
\hline Target vessel MI & $9(1.2)$ & $10(1.3)$ & 0.82 \\
\hline TLR & $42(5.6)$ & $29(3.8)$ & 0.11 \\
\hline $\begin{array}{l}\text { Stent thrombosis } \\
\text { (definite) }\end{array}$ & $6(0.8)$ & $7(0.9)$ & 0.79 \\
\hline $\begin{array}{l}\text { Stent thrombosis } \\
\text { (definite or probable) }\end{array}$ & $7(0.9)$ & $8(1.0)$ & 0.80 \\
\hline Values are number & &
\end{tabular}

Values are number of events (Kaplan-Meier estimates in \%). MI: myocardial infarction; TLF: target lesion failure; TLR: target lesion revascularisation

\section{Discussion}

This is the first analysis comparing the bio-engineered COMBO stent with newer-generation DES, showing no significant differences in clinical outcomes between the COMBO and PROMUS/ Resolute Integrity in a balanced cohort at two-year follow-up. Furthermore, the current analysis shows that baseline clinical and angiographic characteristics are different among all-comers trials, and low rates of target lesion failure are observed at two-year follow-up after DES implantation.

\section{COMBO VERSUS CURRENT MONOTHERAPY DES}

This analysis is the first to compare the COMBO stent with current DES. No significant differences were observed in terms of TLF, any individual endpoints and definite/probable stent thrombosis. Target lesion revascularisation was non-significantly higher in patients treated with COMBO, with an increase of revascularisation between six and nine months post index procedure. Although there was no scheduled repeat angiography in the REMEDEE registry, there might be a slight recall bias due to the fact that the COMBO stent is a newer device, and patients with persistent angina were more easily scheduled for repeat angiography.

\section{ALL-COMERS PCI COHORTS}

In the present analysis we found that the baseline characteristics of two large all-comers PCI patient cohorts were different, despite similar inclusion and exclusion criteria. When comparing clinical and angiographic characteristics, there were notable differences in age, hypertension, previous PCI or MI, location of lesion, number of lesions, lesion type and lesion length. This could be explained by the fact that the DUTCH PEERS trial is a Dutch trial, where patients were enrolled in the Netherlands only, while the REMEDEE registry enrolled patients in five European countries. Also, there might be differences in patients who want to participate in a randomised trial or registry. De Boer et al previously compared participants and non-participants of a single high-volume centre in two "all-comer" randomised PCI trials and found that these two groups differed significantly in baseline characteristics and clinical outcome; the authors explained this by the fact that only half of the target population was enrolled ${ }^{15}$. While the all-comers design of clinical studies may not always fully represent "real-world" clinical practice, von Birgelen et al recently found that five-year clinical outcome was similar for participants in a randomised "most-comer" DES study with a very high enrolment rate versus the complete cohort of patients who had been eligible for trial enrolment ${ }^{16}$.

If we compare the baseline characteristics with other trials $\left(\right.$ LEADERS $^{17}$, COMPARE ${ }^{18}$, SPIRIT IV ${ }^{19}$ ), baseline characteristics are similar but do alter frequently, e.g., age (lowest mean: 63 years, highest: 65 years), hypertension (lowest: 44\%, highest: 77\%), previous PCI (lowest: 13\%, highest: 37\%), previous MI (lowest: 15\%, highest: 33\%). Attention should be given to baseline characteristics when interpreting all-comers PCI trial results. In this study we accounted for multiple confounders by propensity score matching; there were no differences between COMBO and PROMUS Element/Resolute Integrity patients.

\section{CLINICAL OUTCOMES TWO YEARS AFTER STENT PLACEMENT}

In the PRODIGY study, subgroup analyses were performed comparing the clinical combined endpoint of death, MI and target vessel revascularisation after BMS or DES placement at two years. The endpoint occurred in $32.1 \%$ of patients treated with $\mathrm{BMS}^{20}$. In this same study, the endpoint occurred in $27.8 \%$ of patients treated with zotarolimus-eluting Endeavor ${ }^{\circledR}$ Sprint stents (ZES-S) (Medtronic), 26.2\% in paclitaxel-eluting stents (PES) and 19.2\% in everolimus-eluting stents (EES). A major decrease in adverse events was noted with the use of newer DES.

The adverse event rates after PCI continue to decrease. In the LEADERS trial two-year results, a further decline in event rates was noticed, comparing the first-generation DES, a sirolimus-eluting stent, with second-generation DES, a biolimus-eluting stent. 
The combined cardiac death, MI and clinically indicated TLR rate was $11.9 \%$ in BES and $13.6 \%$ in $\mathrm{SES}^{21}$. The COMPARE trial twoyear results also showed lower event rates with second-generation DES (rate of all death, MI, and TVR: $9.0 \%$ in EES and $13.7 \%$ in PES ${ }^{22}$. SPIRIT IV two-year results were also in line with these findings, showing lower events in second-generation $\mathrm{DES}^{23}$. To evaluate the efficacy of the bio-engineered anti-CD34 antibody layer, a comparison might be carried out with a DES eluting sirolimus. If we compare the two-year results of this balanced cohort with monotherapy SES from LEADERS, we notice a lower event rate in the COMBO stent group.

The theoretical benefit of the novel dual-therapy stent technology is to reduce the healing time and potentially reduce the DAPT duration. This could specifically benefit patients who have a high risk of bleeding or are scheduled for operation, or patients who are unlikely to adhere to medication. The BioFreedom ${ }^{\mathrm{TM}}$ stent (Biosensors Interventional Technologies, Singapore) with one month DAPT has been demonstrated to be safer than BMS in patients with a high risk of bleeding ${ }^{23}$. Myocardial infarction and/or stent thrombosis was observed in $8.2 \%$ of patients with a high risk of bleeding treated with BioFreedom at two-year follow-up. These data cannot be directly compared to our data, due to patient selection. Future trials would be needed to address the differences in performance between BioFreedom and the COMBO stent.

\section{Limitations and strengths}

First, the main limitation of these analyses is that the data are not randomised. The propensity score was calculated based on 13 pre-specified baseline and angiographic characteristics, but there could be other factors playing a role in clinical outcome that were not taken into account (e.g., chronic kidney disease and depressed left ventricular ejection fraction). Also, matching was performed with only limited angiographic characteristics. This is an important limitation that we acknowledge. The REMEDEE registry did not have core laboratory-adjudicated data on angiographic characteristics. Angiographic data were entered into the database by the sub-investigator of the site. All angiographic data in the DUTCH PEERS trial were core laboratory-adjudicated and obtained by means of quantitative coronary angiography (QCA; Medis, Leiden, the Netherlands). However, all events were adjudicated by an independent clinical events committee in the DUTCH PEERS trial and also in the REMEDEE registry. In addition, we could not correct for the fact that the patients treated in DUTCH PEERS were all patients in the Netherlands, and the REMEDEE registry consisted of European patients. The COMBO is compared with two different DES together (either Resolute Integrity or PROMUS Element). The results of the randomised DUTCH PEERS trial showed non-inferiority of Resolute Integrity to PROMUS Element, allowing these DES results to be pooled. For the main analysis we used the pooled set because of the increased power of a larger set of matched pairs. The separate analyses in Supplementary Table 1-Supplementary Table $\mathbf{5}$ show comparable outcomes ${ }^{24}$.
This analysis is the first to compare the COMBO stent with other newer-generation DES in a balanced cohort at two-year follow-up. Results of the study evaluating short (three months) versus standard (12 months) duration of DAPT in ACS patients, the REDUCE study, are awaited. Randomised data comparing the COMBO with the everolimus-eluting XIENCE stent (Abbott Vascular, Santa Clara, CA, USA) are expected from the forthcoming HARMONEE trial (NCT02073565).

\section{Conclusions}

In a propensity-matched cohort of patients treated with the novel COMBO stent and patients treated with either a PROMUS Element or Resolute Integrity DES, no differences were found in the clinical endpoint target lesion failure, with overall low adverse event rates. However, randomised trials are needed to demonstrate the equivalence of the COMBO stent to other current-generation DES.

\section{Impact on daily practice}

The dual-therapy stent technology has been evaluated in allcomers patients and has shown good clinical results. Currently, there are no data comparing the clinical results with other commonly used newer-generation DES, such as the PROMUS Element and Resolute Integrity. Two-year clinical follow-up of the COMBO stent shows low event rates, not significantly different from the PROMUS Element and Resolute Integrity stents, in a balanced cohort. Randomised controlled trials evaluating the clinical results after COMBO stent deployment are currently being conducted and their results are keenly anticipated.

\section{Acknowledgements}

We acknowledge all patients for their participation in both studies and all interventional cardiologists and study nurses for conducting these studies. We especially thank all principal investigators of the DUTCH PEERS trial and REMEDEE registry: P. Danse, G. Jessurun, R. Hautvast, G.K. van Houwelingen, A.R. Schramm, R.M. Tjon Joe Gin, J.W. Louwerenburg, F.H.A.F. de Man, M.G. Stoel, G. Linssen, S.A.M. Saïd, M.B. Nienhuis, P.M.J. Verhorst, M.W.Z. Basalus, C.J.M. Doggen, K. Tandjung, P. den Heijer, I.B.A. Menown, A. Erglis, H. Suryapranata, K.E. Arkenbout, A. Iñiguez, A.W.J. van 't Hof and P. Muller.

\section{Funding}

The AMC received an unrestricted research grant from OrbusNeich BV. Boston Scientific and Medtronic equally funded the DUTCH PEERS trial.

\section{Conflict of interest statement}

C. von Birgelen has received consultancy fees from Biotronik, Boston Scientific, and Medtronic, and institutional grant support from AstraZeneca, Biotronik, Boston Scientific, and Medtronic. R.J. de Winter has received consultancy fees from OrbusNeich and 
Abbott, and grant support from AstraZeneca, Stentys and Tryton Medical. The other authors have no conflicts of interest to declare.

\section{References}

1. Moses JW, Leon MB, Popma JP, Fitzgerald PJ, Holmes DR, O'Shaughnessy C, Caputo RP, Kereiakes DJ, Williams DO, Teirstein PS, Jaeger JL, Kuntz RE; SIRIUS Investigators. Sirolimuseluting stents versus standard stents in patients with stenosis in a native coronary artery. $N$ Engl J Med. 2003;349:1315-23.

2. Stettler C, Wandel S, Allemann S, Kastrati A, Morice MC, Schömig A, Pfisterer ME, Stone GW, Leon MB, de Lezo JS, Goy JJ, Park SJ, Sabaté M, Suttorp MJ, Kelbaek H, Spaulding C, Menichelli M, Vermeersch P, Dirksen MT, Cervinka P, Petronio AS, Nordmann AJ, Diem P, Meier B, Zwahlen M, Reichenbach S, Trelle S, Windecker S, Jüni P. Outcomes associated with drug-eluting and bare-metal stents: a collaborative network meta-analysis. Lancet. 2007;370:937-48.

3. Stone GW, Ellis SG, Cox DA, Hermiller J, O’Shaughnessy C, Mann JT, Turco M, Caputo R, Bergin P, Greenberg J, Popma JJ, Russell ME; TAXUS-IV Investigators. A polymer-based, paclitaxel-eluting stent in patients with coronary artery disease. $N$ Engl J Med. 2004;350:221-31.

4. Stefanini GG, Holmes DR Jr. Drug-eluting coronary-artery stents. N Engl J Med. 2013;368:254-65.

5. Granada JF, Inami S, Aboodi MS, Tellez A, Milewski K, Wallace-Bradley D, Parker S, Rowland S, Nakazawa G, Vorpahl M, Kolodgie FD, Kaluza GL, Leon MB, Virmani R. Development of a novel prohealing stent designed to deliver sirolimus from a biodegradable abluminal matrix. Circ Cardiovasc Interv. 2010;3: 257-66.

6. Larsen K, Cheng C, Tempel D, Parker S, Yazdani S, den Dekker WK, Houtgraaf JH, de Jong R, Swager-Ten Hoor S, Ligtenberg E, Hanson SR, Rowland S, Kolodgie F, Serruys PW, Virmani R, Duckers HJ. Capture of circulatory endothelial progenitor cells and accelerated re-endothelialization of a bio-engineered stent in human ex vivo shunt and rabbit denudation model. Eur Heart J. 2012;33:120-8.

7. Woudstra P, Kalkman DN, den Heijer P, Menown IB, Erglis A, Suryapranata H, Arkenbout KE, Iñiguez A, van 't Hof AW, Muller P, Tijssen JG, de Winter RJ. 1-Year Results of the REMEDEE Registry: Clinical Outcomes After Deployment of the Abluminal Sirolimus-Coated Bioengineered (Combo) Stent in a Multicenter, Prospective All-Comers Registry. JACC Cardiovasc Interv. 2016;9: 1127-34.

8. Kalkman, DN, Woudstra P, Menown IBA, den Heijer P, van't Hof AW, Erglis A, Suryapranata H, Arkenbout KE, Iñiguez A, Muller P, Tijssen JG, Beijk MAM, de Winter RJ. Two-year clinical outcomes of patients treated with the dual-therapy stent in a 1000 patient all-comers registry. Open Heart. 2017;4:e00634.

9. Stone GW, Teirstein PS, Meredith IT, Farah B, Dubois CL, Feldman RL, Dens J, Hagiwara N, Allocco DJ, Dawkins KD; PLATINUM Trial Investigators. A prospective, randomized evaluation of a novel everolimus-eluting coronary stent: the
PLATINUM (A Prospective, Randomized, Multicenter Trial to Assess an Everolimus-Eluting Coronary Stent System [PROMUS Element] for the Treatment of up to Two De Novo Coronary Artery Lesions) trial. J Am Coll Cardiol. 2011;57:1700-8.

10. Yeung AC, Leon MB, Jain A, Tolleson TR, Spriggs DJ, Mc Laurin BT, Popma JJ, Fitzgerald PJ, Cutlip DE, Massaro JM, Mauri L; RESOLUTE US Investigators. clinical evaluation of the resolute zotarolimus-eluting coronary stent system in the treatment of de novo lesions in native coronary arteries: the RESOLUTE US clinical trial. J Am Coll Cardiol. 2011;57:1778-83.

11. von Birgelen C, Sen H, Lam MK, Danse PW, Jessurun GA, Hautvast RW, van Houwelingen GK, Schramm AR, Gin RM, Louwerenburg JW, de Man FH, Stoel MG, Löwik MM, Linssen GC, Saïd SA, Nienhuis MB, Verhorst PM, Basalus MW, Doggen CJ, Tandjung K. Third-generation zotarolimus-eluting and everolimuseluting stents in all-comer patients requiring a percutaneous coronary intervention (DUTCH PEERS ): a randomised, single-blind, multicentre, non-inferiority trial. Lancet. 2014;383:413-23.

12. Sen H, Lam MK, Löwik MM, Danse PW, Jessurun GA, van Houwelingen KG, Anthonio RL, Tjon Joe Gin RM, Hautvast RW, Louwerenburg JH, de Man FH, Stoel MG, van der Heijden LC, Linssen GC, IJzerman MJ, Tandjung K, Doggen CJ, von Birgelen C. Clinical Events and Patient-Reported Chest Pain in All-Comers Treated With Resolute Integrity and Promus Element Stents: 2-Year Follow-Up of the DUTCH PEERS (DUrable Polymer-Based STent CHallenge of Promus ElemEnt Versus ReSolute Integrity) Randomized Trial (TWENTE II). JACC Cardiovasc Interv. 2015;8: 889-99.

13. Cutlip DE, Windecker S, Mehran R, Boam A, Cohen DJ, van Es GA, Steg PG, Morel MA, Mauri L, Vranckx P, McFadden E, Lansky A, Hamon M, Krucoff MW, Serruys PW; Academic Research Consortium. Clinical end points in coronary stent trials: a case for standardized definitions. Circulation. 2007;115: 2344-51.

14. Vranckx P, Cutlip DE, Mehran R, Kint PP, Silber S, Windecker S, Serruys PW. Myocardial infarction adjudication in contemporary all-comer stent trials: balancing sensitivity and specificity. Addendum to the historical MI definitions used in stent studies. EuroIntervention. 2010;5:871-4.

15. de Boer SP, Lenzen MJ, Oemrawsingh RM, Simsek C, Duckers HJ, van der Giessen WJ, Serruys PW, Boersma E. Evaluating the 'all-comers' design: a comparison of participants in two 'all-comers' PCI trials with non-participants. Eur Heart J. 2011;32:2161-7.

16. von Birgelen C, van der Heijden LC, Basalus MW, Kok MM, Sen H, Louwerenburg HW, van Houwelingen KG, Stoel MG, de Man FH, Linssen GC, Tandjung K, Doggen CJ, van der Palen J, Löwik MM. Five-Year Outcome After Implantation of Zotarolimusand Everolimus-Eluting Stents in Randomized Trial Participants and Nonenrolled Eligible Patients: A Secondary Analysis of a Randomized Clinical Trial. JAMA Cardiol. 2017;2:268-76.

17. Garg S, Sarno G, Serruys PW, de Vries T, Buszman P, Linke A, Ischinger T, Klauss V, Eberli F, Corti R, Wijns W, Morice MC, 
Di Mario C, van Geuns RJ, Eerdmans P, van Es GA, Meier B, Jüni P, Windecker S. The twelve-month outcomes of a biolimus eluting stent with a biodegradable polymer compared with a sirolimus eluting stent with a durable polymer. EuroIntervention. 2010;6:233-9.

18. Kedhi E, Joesoef KS, McFadden E, Wassing J, van Mieghem C, Goedhart D, Smits PC. Second-generation everolimus-eluting and paclitaxel-eluting stents in real-life practice (COMPARE): a randomised trial. Lancet. 2010;375:201-9.

19. Stone GW, Rizvi A, Newman W, Mastali K, Wang JC, Caputo R, Doostzadeh J, Cao S, Simonton CA, Sudhir K, Lansky AJ, Cutlip DE, Kereiakes DJ; SPIRIT IV Investigators. Everolimuseluting versus paclitaxel-eluting stents in coronary artery disease. N Engl J Med. 2010;362:1663-74.

20. Valgimigli M, Tebaldi M, Borghesi M, Vranckx P, Campo G, Tumscitz C, Cangiano E, Minarelli M, Scalone A, Cavazza C, Marchesini J, Parrinello G; PRODIGY Investigators. Two-year outcomes after first- or second-generation drug-eluting or bare-metal stent implantation in all-comer patients undergoing percutaneous coronary intervention: a pre-specified analysis from the PRODIGY study (PROlonging Dual Antiplatelet Treatment After Grading stent-induced Intimal hyperplasia studY). JACC Cardiovasc Interv. 2014;7:20-8.

21. Klauss V, Serruys PW, Pilgrim T, Buszman P, Linke A, Ischinger T, Eberli F, Corti R, Wijns W, Morice MC, di Mario C, van Geuns RJ, van Es GA, Kalesan B, Wenaweser P, Jüni P, Windecker S. 2-year clinical follow-up from the randomized comparison of biolimus-eluting stents with biodegradable polymer and sirolimus-eluting stents with durable polymer in routine clinical practice. JACC Cardiovasc Interv. 2011;4:887-95.

22. Smits PC, Kedhi E, Royaards KJ, Joesoef KS, Wassing J, Rademaker-Havinga TA, McFadden E. 2-year follow-up of a randomized controlled trial of everolimus- and paclitaxel-eluting stents for coronary revascularization in daily practice: COMPARE
(Comparison of the everolimus eluting XIENCE-V stent with the paclitaxel eluting TAXUS LIBERTÉ stent in all-comers: a randomized open label trial). J Am Coll Cardiol. 2011;58:11-8.

23. Stone GW, Rizvi A, Sudhir K, Newman W, Applegate RJ, Cannon LA, Maddux JT, Cutlip DE, Simonton CA, Sood P, Kereiakes DJ; SPIRIT IV Investigators. Randomized comparison of everolimus- and paclitaxel-eluting stents: 2-year follow-up from the SPIRIT (clinical evaluation of the XIENCE V Everolimus Eluting Coronary Stent System) IV trial. J Am Coll Cardiol. 2011; 58:19-25.

24. Elze MC, Gregson J, Baber U, Williamson E, Sartori S, Mehran R, Nichols M, Stone GW, Pocock SJ. Comparison of Propensity Score Methods and Covariate Adjustment: Evaluation in 4 Cardiovascular Studies. J Am Coll Cardiol. 2017;69:345-357.

\section{Supplementary data}

Supplementary Table 1A. PROMUS Element and Resolute Integrity and COMBO baseline characteristics before PS matching. Supplementary Table 1B. PROMUS Element with Resolute Integrity and $\mathrm{COMBO}$ baseline characteristics before PS matching. Supplementary Table 2. Resolute Integrity versus COMBO baseline characteristics after PS matching.

Supplementary Table 3. Clinical endpoints at two-year followup - COMBO versus Resolute Integrity.

Supplementary Table 4. PROMUS Element versus COMBO baseline characteristics after PS matching.

Supplementary Table 5. Clinical endpoints at two-year followup - COMBO versus PROMUS Element.

The supplementary data are published online at:

http://www.pcronline.com/

eurointervention/125th_issue/188 